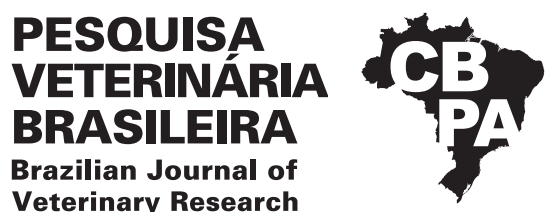

Pesq. Vet. Bras. 40(4):300-305, April 2020 DOI: 10.1590/1678-5150-PVB-6245

Original Article

Animal Morphophysiology

ISSN 0100-736X (Print)

ISSN 1678-5150 (Online)

\title{
Markers of inflammation and insulin resistance in dogs before and after weight loss versus lean healthy dogs ${ }^{1}$
}

\author{
Juliana T. Jeremias ${ }^{2}$, Thiago H.A. Vendramini ${ }^{3}$, Roberta B.A. Rodrigues ${ }^{3}$, \\ Mariana P. Perini ${ }^{3}$, Vivian Pedrinelli ${ }^{4}$, Fabio A. Teixeira ${ }^{4}$, \\ Márcio A. Brunetto ${ }^{3 *}$ (D) and Cristiana F.F. Pontieri ${ }^{2}$
}

\begin{abstract}
Jeremias J.T., Takeara P., Vendramini T.H.A., Rodrigues R.B.A., Perini M.P., Pedrinelli V., Teixeira F.A., Brunetto' M.A. \& Pontieri C.F.F. 2020. Markers of inflammation and insulin resistance in dogs before and after weight loss versus lean healthy dogs. Pesquisa Veterinária Brasileira 40(4):300-305. Departamento de Nutrição e Produção Animal, Faculdade de Medicina Veterinária e Zootecnia, Universidade de São Paulo, Av. Duque de Caxias Norte 225, Pirassununga, SP 19635-900, Brazil. E-mail: mabrunetto@usp.br

Chronic low-grade inflammation in obesity is characterized by an increased production of pro-inflammatory cytokines that contribute to insulin resistance. For this study body composition, markers of inflammation and of insulin resistance in dogs before and after weight loss were compared to those of lean dogs. Eleven client-owned obese adult dogs underwent a weight loss program with commercial dry food for weight loss and reached an ideal body condition score (BCS) six months after the beginning of the weight loss program. A Control Group of nine dogs with ideal BCS were selected for the comparison. Shapiro-Wilk test was used to test for normality, Mann Whitney were used for non-normally distributes data, and Student t-test was used for normally distributed parameters. In the Obese Group body fat decreased from $41.6 \%(30.7-58.6)$ to $29.1 \%(18.6-46.3)(\mathrm{P}<0.01)$ and dogs maintained lean body mass throughout the weight loss program $(\mathrm{P}>0.05)$. Obese dogs presented higher concentration of fructosamine, triglycerides, insulin, IGF-1 and leptin than the Control Group before weight reduction $(\mathrm{P}<0.05)$. Serum concentrations of triglycerides, IL-2, IL-6, TNF- $\alpha$, insulin, leptin and IGF-1 decreased after weight loss $(\mathrm{P}<0.01)$, and these concentrations were similar to the Control Group $(\mathrm{P}>0.05)$, except for leptin $(\mathrm{P}<0.001)$. No alteration on peptide $Y Y$ was found. Leptin $(r=0.60, P=0.01)$, fructosamine $(r=0.44, P=0.02)$ and triglycerides $(r=0.40, \mathrm{P}=0.04)$ concentrations correlated with the reduction of body fat. Weight loss reduced the concentrations of inflammatory and insulin resistance markers and most parameters became similar to dogs that have always been lean, reinforcing the importance of weight loss in small animal practice.
\end{abstract}

INDEX TERMS: Inflammation, insulin resistance, dogs, weight loss, healthy dogs, adipocytokines, canine, cytokines, leptin, obesity.

RESUMO.- [Marcadores de inflamação e resistência à insulina em cães antes e depois da perda de peso versus cães saudáveis e magros.] A inflamação crônica de baixo grau na obesidade é caracterizada pela produção aumentada de citocinas pró-inflamatórias que contribuem para a resistência à insulina. Para este estudo a composição corporal e os

\footnotetext{
${ }^{1}$ Received on September 6, 2019.

Accepted for publication on November 7, 2019.

${ }^{2}$ Grandfood Indústria e Comércio Ltda, Rodovia SP-215 Km 199, Fazenda Santa Gertrudes, Dourado, SP 13590-000, Brazil.

${ }^{3}$ Departamento de Nutrição e Produção Animal, Faculdade de Medicina Veterinária e Zootecnia, Universidade de São Paulo (USP), Av. Duque de
}

marcadores de inflamação e de resistência à insulina em cães antes e após a perda de peso foram comparados aos de cães magros. Onze cães adultos obesos pertencentes a tutores foram incluídos em um programa de perda de peso com ração comercial hipocalórica e alcançaram escore de condição corporal (ECC) ideal seis meses após o início do

\footnotetext{
Caxias Norte 225, Pirassununga, SP 19635-900, Brazil. *Corresponding author: mabrunetto@usp.br

${ }^{4}$ Departamento de Clínica Médica, Faculdade de Medicina Veterinária e Zootecnia (FMVZ), Universidade de São Paulo (USP), Avenida Prof. Dr. Orlando Marques de Paiva 87, Cidade Universitária, São Paulo, SP 05508-270, Brazil.
} 
regime. Um Grupo Controle de nove cães com ECC ideal foi selecionado para a comparação. 0 teste de Shapiro-Wilk foi usado para testar a normalidade, Mann Whitney foi usado para análise dos dados que não atenderam distribuição normal e o teste $t$ de Student foi usado para parâmetros que atenderam a normalidade. No Grupo Obesidade, a gordura corporal diminuiu de $41,6 \%(30,7-58,6)$ para $29,1 \%(18,6-$ $46,3)(\mathrm{P}<0,01)$ e os cães mantiveram massa magra ao longo do programa de perda de peso $(\mathrm{P}>0,05)$. Cães obesos apresentaram maior concentração de frutosamina, triglicérides, insulina, IGF-1 e leptina do que o Grupo Controle antes da redução de peso $(\mathrm{P}<0,05)$. As concentrações séricas de triglicerídeos, IL-2, IL-6, TNF- $\alpha$, insulina, leptina e IGF-1 diminuíram após a perda de peso $(\mathrm{P}<0,01)$ e, essas concentrações foram semelhantes ao Grupo Controle (P>0,05), com exceção da leptina $(\mathrm{P}<0,001)$. Nenhuma alteração no peptídeo YY foi encontrada. As concentrações de leptina $(\mathrm{r}=0,60 ; \mathrm{P}=0,01)$, frutosamina $(\mathrm{r}=0,44 ; \mathrm{P}=0,02)$ e triglicerídeos $(\mathrm{r}=0,40 ; \mathrm{P}=0,04)$ correlacionaram-se com a redução da gordura corporal. A perda de peso reduziu as concentrações de marcadores inflamatórios e de resistência à insulina e a maioria dos parâmetros tornaram-se semelhante aos dos cães que sempre foram magros, reforçando a importância da perda de peso na prática clínica de pequenos animais.

TERMOS DE INDEXAÇÃO: Inflamação, insulina, cães, perda de peso, cães saudáveis, adipocitocinas, caninos, citocinas, leptina, obesidade.

\section{INTRODUCTION}

The adipose tissue in addition to serving as a reservoir of energy, can protect organs from direct impact and is responsible for the synthesis and secretion of various hormones and cytokines called adipokines (Zoran 2010). Chronic low-grade inflammation in obese dogs is characterized by increased secretion of proinflammatory cytokines that reduce glucose tolerance, increase insulin resistance, and may cause hyperlipidemia and several other significant health problems, such as cardiorespiratory and orthopedic alterations (Gayet et al. 2004, German 2006, German et al. 2009, Brunetto 2010, Brunetto et al. 2011).

Most studies with humans and rodents indicate that obese individuals present higher levels of pro-inflammatory cytokines (IL-6 and TNF- $\alpha$ ), IGF-1 and leptin than non-obese individuals (Hotamisligil et al. 1995, Shoelson et al. 2007). However, studies in obese dogs have shown that the values of IL- 6 and TNF- $\alpha$ are often below the lower limit of detection (Tvarijonaviciute et al. 2012, Bastien et al. 2015), although some studies suggest that canine obesity is also correlated with low-grade inflammation (Eirmann et al. 2009, German et al. 2009, Frank et al. 2015).

In humans, IL-6, TNF- $\alpha$ and IGF- 1 are blood markers of insulin resistance, and their overproduction is related to this syndrome (Leahy \& Vandekerkhove 1990, Hotamisligil et al. 1995). Elevated IGF-1 concentration has an impact on insulin secretion, which could lead to insulin resistance over time (Leahy \& Vandekerkhove 1990). In obese dogs, impairment in both TNF- $\alpha$ and IGF-1 plasma concentration is associated with insulin resistance (Gayet et al. 2004).

The purpose of this study was to assess inflammatory adipokines profile and insulin resistance in obese dogs and to determine the effect of subsequent weight loss, as well as to compare these findings with lean adult dogs.

\section{MATERIALS AND METHODS}

Ethics statement. All experimental procedures agreed with the ethical principles in animal experimentation adopted by the Brazilian College of Animal Experimentation (COBEA) and was approved and agree with Ethical Principles in Animal Research adopted by Ethic Committee on Animal Use of the Grandfood Indústria e Comércio LTDA, Brazil.

Animals and experimental design. A total of twenty dogs were used in this study and were divided in two groups. The Experimental Group consisted of eleven client-owned obese adult dogs of different breeds (4 mixed-breed, 4 Labrador Retrievers, 2 Dachshunds and 1 Cocker Spaniel), three males and eight females ( 5 neutered females, 3 intact females and 3 intact males), with body condition score (BCS) 7,8 or 9 on a scale of 1 to 9 (Laflamme 1997) which were submitted to a weight loss program. All dogs of the Experimental Group were housed in their owner's home in the city of Dourado, Brazil.

The Control Group consisted of nine healthy kennel dogs from an animal nutrition center (Dourado, Brazil). They were of different breeds (2 Labrador Retrievers, 3 Cocker Spaniels, 2 American Pit bulls, 1 Beagle and 1 Collie) with ideal BCS of 5 on a scale of 1 to 9 (Laflamme 1997), five males and four females ( 2 neutered females, 2 intact females and 5 intact males).

Median age of the Obese Group was 4 years (range 2-12 years), and median age of the Control Group was 7 years (range 2-12 years). Median body weight of the Obese Group before weight loss was $36 \mathrm{~kg}$ (range $9.1-64.5 \mathrm{~kg}$ ) and median body weight for the Control Group was $26 \mathrm{~kg}$ (range 9.8-46.9 kg). The animals of both Control and Experimental Groups were referred to the Nutritional Development Center (PremieR pet, Dourado, Brazil) for evaluation during the study's period. All dogs were evaluated by the same veterinarian for determination of BCS; assessed by visual inspection and palpation of strategic anatomical areas: ribs, subcutaneous fat and waist silhouette (Laflamme 1997). Animals from both Control and Obese Groups were considered healthy by complete blood cell count, biochemical parameters, and clinical examination. Dogs with previously diagnosed ongoing diseases other than obesity were not considered for this study.

Weight loss program and experimental design. The Control Group animals were evaluated and had blood samples collected in the beginning of the study period. They were fed a maintenance diet (Premier Formula Raças Grandes Adultos, Premier Pet), with metabolizable energy (ME) of $3.9 \mathrm{kcal} / \mathrm{g}$ and macronutrient profile of $66.3 \mathrm{~g} / 1000 \mathrm{kcal}$ of crude protein, $35.7 \mathrm{~g} / 1000 \mathrm{kcal}$ of fat, $100.7 \mathrm{~g} / 1000 \mathrm{kcal}$ of starch and $9.0 \mathrm{~g} / 1000 \mathrm{kcal}$ of total dietary fiber based on ME provided by manufacturer. The mean energy requirement of the Control Group was $117 \mathrm{kcal}$ per $\mathrm{kg}^{0.75}$, based on intake that maintained body weight.

The Experimental Group underwent a 6-month weight loss program to reach an ideal BCS of 5 on a scale of 1 to 9 (Laflamme 1997). They were fed twice daily with a commercial dry food for weight loss (Premier Nutrição Clínica Obesidade Cães, Premier Pet). The ME of the dry diet was $2.7 \mathrm{kcal} / \mathrm{g}$ as informed by manufacturer, and the macronutrient profile was $119 \mathrm{~g} / 1000 \mathrm{kcal}$ of crude protein, $27 \mathrm{~g} / 1000 \mathrm{kcal}$ of fat, $54 \mathrm{~g} / 1000 \mathrm{kcal}$ of starch and $50 \mathrm{~g} / 1000 \mathrm{kcal}$ of total dietary fiber based on ME provided by manufacturer. The energy intake was restricted, corresponding to $60 \%$ of the maintenance energy requirements calculated for an individual target weight of minus $15 \%$ of the first assessment weight (Brunetto et al. 2011). Throughout the experimental period, the obese dogs were kept in their homes, being cared for by their owners. Records of body weight and BCS were updated every fifteen days by the same person, and 
adjustments to food amount were made to keep weight loss rate around 1 to $2 \%$ of body weight per week (Brunetto et al. 2011).

Average weekly body weight loss rate was calculated and sessions of exercise of at least 20 minutes per day were recommended. Body composition was determined in the beginning of the trial for both lean and obese dogs and after the weight loss program for the obese dogs, the method used (deuterium oxide dilution) and the values of fat mass and lean mass were calculated. according to Brunetto et al. (2011). Serum concentrations of fructosamine, triglycerides, interleukin-2 (IL-2), interleukin-6 (IL-6), tumor necrosis factor-alpha (TNF- $\alpha$ ), insulin, leptin, insulin-like growth factor-1 (IGF-1) and peptide YY (PYY) were analyzed before and after weight loss for the Obese Group and in the beginning of the trial for the Control Group.

Blood collection and storage. All dogs were fasted overnight, with free access to water, and blood samples were collected by jugular venipuncture the following morning, once before the beginning and once after weight loss period. Immediately after the collection, samples were centrifuged at $3000 \mathrm{x}$ g for 10 minutes, and the serum was divided into 4 aliquots and then placed into $-20^{\circ} \mathrm{C}$ for immediate analysis of fructosamine and triglycerides and into $-70^{\circ} \mathrm{C}$ storage freezer until other assays were performed.

Serum analysis of fructosamine and triglycerides. Fasting serum fructosamine and triglycerides were measured with commercial kit by colorimetric methods (Labtest Diagnóstica S.A., Lagoa Santa, Brazil). The assays were performed according to manufacturer's protocol at the research laboratory.

Circulating concentrations of cytokines, insulin, leptin, PYY and IGF-1. Serum IL-2, IL- 6 and TNF- $\alpha$ were measured with Luminex-based canine cytokine assay according to manufacturer's instructions (Milliplex ${ }^{\circledR}$ MAP canine cytokine Magnetic Bead Panel, Millipore, Billerica, Massachusetts, USA). The intra and inter assay coefficients of variation were $7.5 \%$ and $17.0 \%$ for IL-2 (minimum limit of detection $=3.5 \mathrm{pg} / \mathrm{mL}$ ), $7.3 \%$ and $15.0 \%$ for IL- 6 (minimum limit of detection $=3.7 \mathrm{pg} / \mathrm{mL}$ ) and $6.1 \%$ and $15.0 \%$ for TNF- $\alpha$ (minimum limit of detection $=6.1 \mathrm{pg} / \mathrm{mL}$ ). Serum insulin, leptin and PYY were measured using a Luminex-based assay (Milliplex ${ }^{\circledR}$ Canine Gut Hormone Magnetic Panel, Millipore, Billerica, Massachusetts, USA). The intra and inter assay coefficients of variation were $6.7 \%$ and $7.0 \%$ for insulin (minimum limit of detection $=52.8 \mathrm{pg} / \mathrm{mL}$ ), $4.7 \%$ and $8.0 \%$ for leptin (minimum limit of detection $=80.6 \mathrm{pg}$ / $\mathrm{mL}$ ) and $3.9 \%$ and $7.0 \%$ for PYY (minimum limit of detection = $11.2 \mathrm{pg} / \mathrm{mL}$ ). Serum IGF-1 was measured using a commercial enzyme immunoassay (Enzyme-linked Immunosorbent Assay kit, Uscn Life Science Inc., Wuhan, China). The intra and inter assay coefficients of variation were $9.9 \%$ and $12.0 \%$ (minimum limit of detection = $0.9 \mathrm{pg} / \mathrm{mL}$ ). The assays were performed at the IgAc (Institute Genese of Scientific Analyses, São Paulo, Brazil) according to manufacturer's protocol. All samples analyses were made in duplicate.
Statistical analysis. All parameters were tested with the ShapiroWilk normality test. For non-normally distributed data the Wilcoxon matched paired test was used to compare obese dogs before and after weight loss and Mann Whitney rank test to compare obese dogs with the Control Group. A paired t test was performed for normally distributed parameters to compare obese dogs before and after weight loss and an unpaired test was performed to compare obese dogs with the Control Group. Spearman (non-normally distributed data) and Pearson (normally distributed data) rank correlation with a two-tailed p-value were used to evaluate association between body fat (\%) and other parameters. Differences were considered significant if $\mathrm{P}<0.05$. Data are presented as medians (with range). Statistical analysis was performed with Graph-Pad Prism 5.02 for Windows (GraphPad Software, San Diego, USA).

\section{RESULTS}

Weight loss program. The obese dogs presented BCS 9 (4 dogs), BCS 8 (5 dogs) and BCS 7 (2 dogs) (Laflamme 1997), with a median BCS of 8 . All the obese dogs achieved an ideal BCS of 5 within 6 months. The weight loss program resulted in a median weekly weight loss rate of $0.86 \%(0.49-1.19 \%)$ and dogs achieved a $21.8 \%$ (14.8-28.6\%) weight reduction in 180 (126-281) days. Body fat mass decreased from $41.6 \%$ (30.7-58.6\%) to 29.1\% (18.6-46.3\%) ( $\mathrm{P}<0.01)$. All obese dogs maintained lean body mass after achieving ideal body condition score $(\mathrm{P}>0.05)$. Body composition of obese and of Control Group are shown in Table 1.

Metabolic parameters and markers of inflammation and insulin resistance. The concentrations of all the serum parameters evaluated can be observed in Table 2. Obese dogs presented higher concentration of fructosamine and triglycerides before weight loss when compared to the Control Group $(\mathrm{P}<0.05)$. There was a decrease in serum concentrations of triglycerides when comparing obese dogs before and after weight loss $(\mathrm{P}<0.001)$, but no differences in serum fructosamine were observed $(\mathrm{P}=0.185)$. However, after the weight loss program there was no difference in fructosamine and triglycerides when the Obese Group was compared to the Control Group (Figure 1).

Insulin, leptin and IGF-1 serum concentrations after weight loss of obese dogs decreased $(\mathrm{P}<0.05)$, and were significantly higher in obese dogs when compared to the Control Group $(\mathrm{P}<0.05)$. After weight loss, these concentrations were similar to the ones of the Control Group ( $>>0.05$ ), except for leptin, which was still higher in the obese dogs after weight loss than the dogs in the Control Group $(\mathrm{P}<0.01)$. Serum concentrations of cytokines IL- 2 and IL- 6 decreased after weight loss $(\mathrm{P}<0.01)$, but were no different from the Control Group ( $P>0.05)$. No differences on fasting serum concentration of PYY were found between groups of dogs studied $(\mathrm{P}>0.05)$

Table 1. Body composition of obese dogs before and after weight loss program, and Control Group

\begin{tabular}{lccc}
\hline & \multicolumn{2}{c}{ Obese dogs Group (n=11) } & $\begin{array}{c}\text { Control Group (n=9) } \\
\text { Median (range) }\end{array}$ \\
\cline { 2 - 3 } & $\begin{array}{c}\text { Before weight loss } \\
\text { Median (range) }\end{array}$ & $\begin{array}{c}\text { After weight loss } \\
\text { Median (range) }\end{array}$ & $27.34^{\mathrm{b}}(10.25-34.97)$ \\
Body fat (\%) & $41.25^{\mathrm{a}}(30.71-58.62)$ & $28.56^{\mathrm{b}}(18.64-46.35)$ & $4.44^{\mathrm{b}}(2.69-13.60)$ \\
Body fat (kg) & $10.53^{\mathrm{a}}(3.45-37.81)$ & $6.44^{\mathrm{b}}(2.47-19.75)$ & $72.66^{\mathrm{b}}(65.03-89.75)$ \\
Lean body mass $(\%)$ & $58.75^{\mathrm{a}}(41.38-69.29)$ & $71.44^{\mathrm{b}}(53.65-81.36)$ & $18.65^{\mathrm{a}}(7.20-40.12)$
\end{tabular}

\footnotetext{
${ }_{\mathrm{a}, \mathrm{b}}$ Means followed by the same letter in the rows do not differ by the Student $\mathrm{t}$-test $(\mathrm{P}<0.05)$, being t-paired test for before weight loss vs after weight loss and $t$ test for independent samples for before weight loss vs Control Group and after weight loss vs Control Group.
} 
(Fig.1). TNF- $\alpha$ concentration was below the detection level on most samples (21 of 31 serum samples evaluated), and therefore it was not possible to compare the groups.

Of the parameters studied, the ones that most correlated with the reduction of fat mass were leptin $(\mathrm{r}=0.61, \mathrm{P}=0.001)$, fructosamine $(\mathrm{r}=0.44, \mathrm{P}=0.028)$ and triglycerides $(\mathrm{r}=0.40, \mathrm{P}=0.048)$.

\section{DISCUSSION}

The weight loss program of obese animals resulted in decrease of fat mass and maintenance of lean mass, which indicates that calorie intake and dietary protein levels of the diet were effective in promoting healthy weight loss. The mean weight loss rate was $0.86 \%$ of body weight per week, an adequate rate for client-owned dogs (Carciofi et al. 2005, German 2006).

Table 2. Blood concentrations of metabolic parameters and markers of inflammation and insulin resistance in obese dogs before and after weight loss program, and in the Control Group of lean dogs

\begin{tabular}{|c|c|c|c|}
\hline & \multicolumn{2}{|c|}{ Obese dogs Group (n=11) } & \multirow{2}{*}{$\begin{array}{c}\text { Control Group (n=9) } \\
\text { Median (range) }\end{array}$} \\
\hline & $\begin{array}{l}\text { Before weight loss } \\
\text { Median (range) }\end{array}$ & $\begin{array}{l}\text { After weight loss } \\
\text { Median (range) }\end{array}$ & \\
\hline Fructosamine $(\mu \mathrm{mol} / \mathrm{l})$ & $230(200-353)$ & $223(141-271)$ & $189(158-218)$ \\
\hline Insulin $(\mathrm{pg} / \mathrm{ml})$ & $376(11-1117)$ & $260(96-419)$ & $219(145-393)$ \\
\hline IL-2 (pg/ml) & $23.8(0.54-656)$ & $5.6(2.5-106)$ & $*$ \\
\hline IL-6 (pg/ml) & $31.9(4.5-594)$ & $11.3(1.3-164)$ & * \\
\hline TNF- $\alpha(\mathrm{pg} / \mathrm{ml})$ & $3.11(0.5-46.9)$ & $1.06(0.11-59.8)$ & $*$ \\
\hline
\end{tabular}

* Most sample values were below detection.
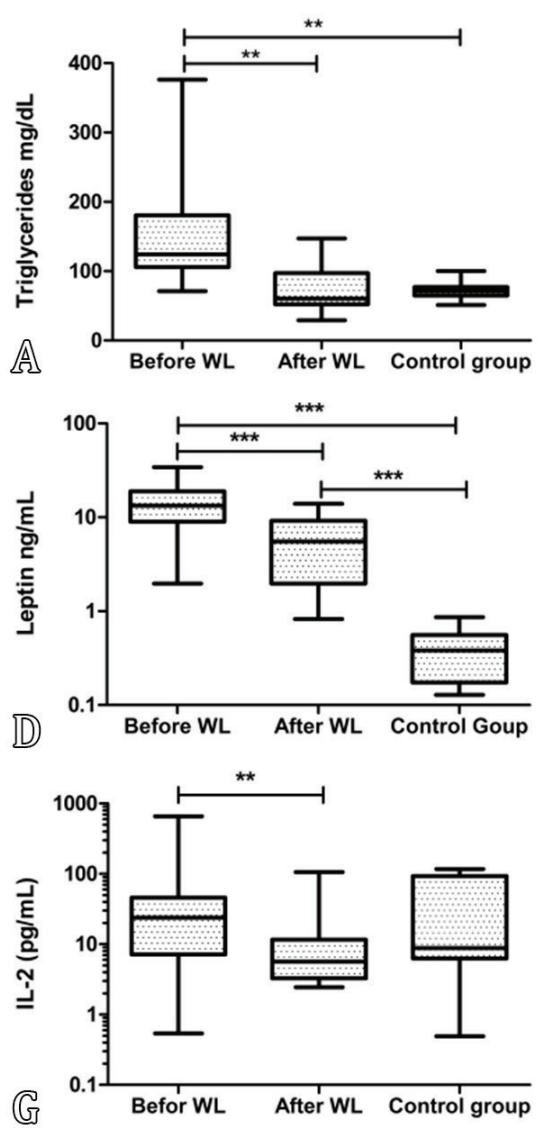
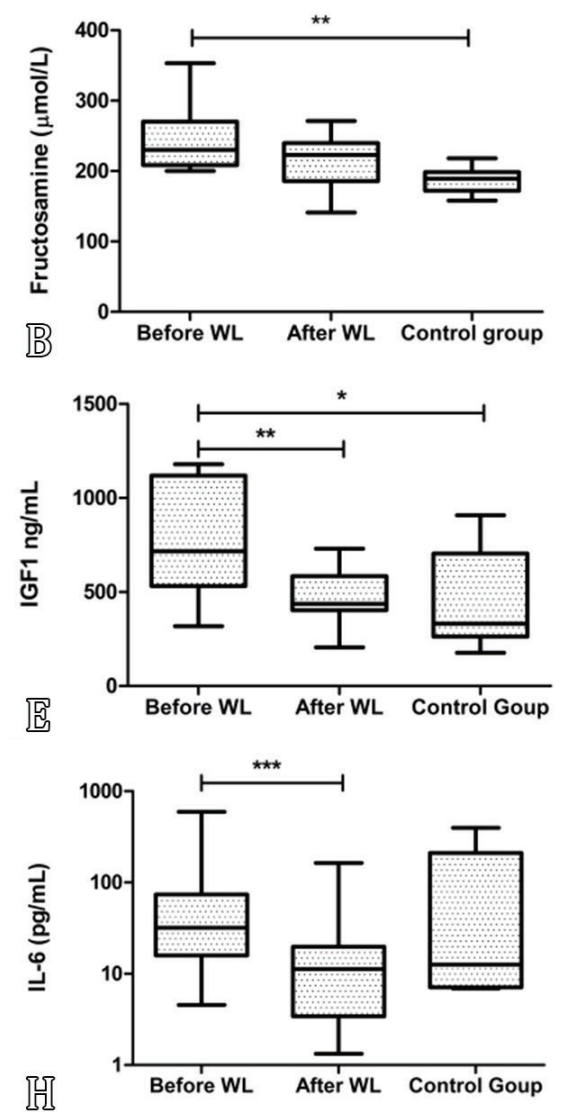
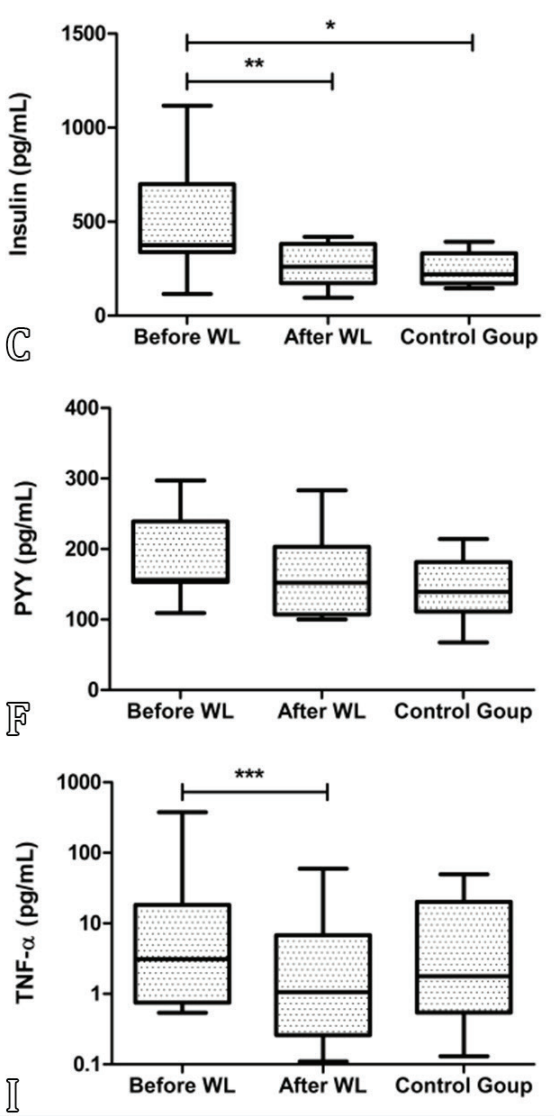

Fig.1. Concentrations of triglycerides, fructosamine, insulin, leptin, IGF-1, PYY, IL-2, IL-6 and TNF- $\alpha$ in dogs before weight loss (Before WL, $\mathrm{n}=11$ ), after weight loss (After WL, $\mathrm{n}=11$ ) and Control Group ( $\mathrm{n}=9$ ). Values are expressed as median (range) and the scale is logarithmic for leptin, IL-2, IL-6 and TNF- $\alpha\left(^{*}\right)$; significantly differences are expressed as $\mathrm{p}<0.05\left(^{* *}\right)$; significantly differences are expressed as $\mathrm{p}<0.001(* * *)$. 
In addition to the beneficial changes in body composition, reduction of body fat mass promoted significant decrease in the serum concentrations of triglycerides, IL-2, IL-6, insulin and IGF-1, as previously demonstrated in dogs, rodents and in humans (Hotamisligil et al. 1995, Blanchard et al. 2004, Jeusette et al. 2005, Shoelson et al. 2007, Eirmann et al. 2009, German et al. 2009, Tvarijonaviciute et al. 2012, Bastien et al. 2015, Frank et al. 2015). Unfortunatly, most samples analyzed for TNF- $\alpha$ concentrations were below detection levels, making it hard to properly take a conclusion about the changes in this parameter before and after weight loss.

Higher serum concentration of triglycerides in obese dogs can be associated with higher body fat mass, as observed in a previously study comparing obese and lean dogs (Eirmann et al. 2009). The results of the current study suggests that insulin resistance is present in obese dogs, as evidenced by elevated serum insulin concentration in this group before weight loss. The concentration of serum insulin decreased significantly in obese dogs after weight loss, suggesting improved insulin sensitivity after dogs lost weight, which supports prior results observed in dogs (German et al. 2009, Bastien et al. 2015).

Previous research found positive correlation between leptin concentration and body fat content and observed that plasma leptin is a good biochemical index of adiposity/obesity in dogs (Ishioka et al. 2002). Other studies observed higher leptin concentration in obese dogs, suggesting that obese dogs, like obese humans, are leptin resistant (Gayet et al. 2004, Jeusette et al. 2005). In the present study, leptin serum concentration was high in obese dogs and had a significant correlation with body fat content. Furthermore, leptin concentrations remained 44\% higher even after achieving ideal BCS when compared to the Control Group, suggesting that immediately after weight loss dogs' metabolism may still present leptin resistance. In contrast, Jeusette et al. (2005) observed that dogs that just lost weight had similar concentration of leptin than lean dogs. It is important to understand that in the current study the composition of the diets used for both groups was different, and along with different housing spaces, this may have influenced markers' concentration levels and so results must be considered with caution.

Receptors that bind insulin and IGF-1 show immunological, structural, and functional analogies, which could explain why IGF-1 has an insulin-like activity, and participates in insulin resistance (Gayet et al. 2004). This present study's results showed that the treatment of obesity may have improved markers of insulin resistance. Blanchard et al. (2004) observed a decrease in IGF-1 concentration after 6 weeks of restriction of energy intake, suggesting that this quick reduction was due to caloric restriction and not to a decrease in body fat mass. The data obtained in the current study corroborates this statement since the concentration of IGF-1 decreased after weight loss, however, it did not correlate with body fat mass $(r=0.07, P=0.7128)$. A more recent study showed a significant reduction in IGF-1 concentration after 3 months of energy restriction to induce rapid weight loss (2-3\% of BW/week) (Tvarijonaviciute et al. 2012).

Reference ranges for circulating cytokines in healthy dogs have not been established yet and many of the studies in obese dogs have shown that the values of common inflammatory biomarkers, such as IL-2, IL-6, and TNF- $\alpha$, are often below the lower limit of detection (Eirmann et al. 2009, German et al. 2009, Wakshlag et al. 2011, Tvarijonaviciute et al. 2012, Bastien et al. 2015, Frank et al. 2015). In this study, IL-2 concentrations were below the kit sensibility in 6 of the 31 serum samples evaluated, 4 of them in obese dogs after weight loss, and IL-6 concentrations in 3 of 31, all of them in obese dogs after weight loss. On the other hand, most of TNF- $\alpha$ concentrations were below the level of detection (21 of 31 serum samples evaluated), suggesting that normal circulating levels of TNF- $\alpha$ are lower since the studied dogs were all healthy, despite obesity.

Even though part of the samples were close to the minimum limit of detection, a significant decrease in concentration of all cytokines studied after weight loss was found, suggesting some influence of adipose tissue on this cytokines secretion. The median values found in Obese Group were higher than the Control Group in all inflammatory cytokines evaluated. However, significant differences were not detected, possibly due to the great variation within Control Group concentrations.

Growth factors have not been related to rodent and human obesity. The growth-factor IL- 2 is more related to possible immune status and less likely to be influenced by obesity status. However, a recent study of obese dogs performed by Bastien et al. (2015) evaluated IL-2 and found decrease in this parameter after weight loss, similar to this study.

Results are in accordance with a recent study that showed fasting serum IL-6 concentrations are elevated in Labrador Retrievers that were overweight or obese when compared to lean dogs from the same breed (Frank et al. 2015). It has been hypothesized that in absence of acute inflammation, fifteen to thirty percent of circulating IL-6 level comes from adipose tissue, including the macrophages and stromal cells contained in the tissue (Mohamed-Ali et al. 1997). However, it is important to highlight that in other studies the concentration of IL- 6 was below the minimum limit of detection (German 2006, Eirmann et al. 2009, Tvarijonaviciute et al. 2012).

Studies have reported increase in TNF- $\alpha$ concentration in obese humans and rodents (Hotamisligil et al. 1995, Shoelson et al. 2007), and TNF- $\alpha$ has been found to also be higher in dogs (Eirmann et al. 2009, German et al. 2009, Bastien et al. 2015, Frank et al. 2015). However, only one study observed that concentrations of TNF- $\alpha$ were higher in obese dogs and decreased significantly after weight loss (Gayet et al. 2004).

No studies that assessed serum PYY concentrations in obese dogs were found in the literature. The lack of response observed in this study may be due to the fact that samples were collected during fasting. In humans, PYY levels are low in the fasting state, rapidly increasing in response to food intake, reaching a peak at $1-2 \mathrm{~h}$ after a meal and then remaining high for several hours (Adrian et al. 1985).

\section{CONCLUSIONS}

The treatment of obesity allows the return of triglycerides, insulin and IGF-1 concentrations to normal levels and the reduction of the concentrations of IL-2 and IL- 6 .

The lack of convergent results in the veterinary literature available suggests that more research is needed to characterize the pro-inflammatory effects of canine obesity and the role of cytokines in insulin resistance and related co-morbidities.

Conflict of interest statement.- The authors have no conflict of interest. 


\section{REFERENCES}

Adrian T.E., Ferri G.L., Bacarese-Hamilton A.J., Fuessl H.S., Polak J.M. \& Bloom S.R. 1985. Human distribution and release of a putative new gut hormone, peptide YY. Gastroenterology 89:1070-1077. <http://dx.doi. org/10.1016/0016-5085(85)90211-2>

Bastien B.C., Patil A. \& Satyaraj E. 2015. The impact of weight loss on circulating cytokines in Beagle dogs. Vet. Immunol. Immunopathol. 163(3/4):174-182. <http://dx.doi.org/10.1016/j.vetimm.2014.12.003><PMid:25576490>

Blanchard G., Nguyeny P., Gayet C., Leriche I., Siliarty B. \& Paragon B-M. 2004. Rapid weight loss with a high-protein low-energy diet allows the recovery of ideal body composition and insulin sensitivity in obese dogs. J. Anim. Sci. 134(supl.8):2148S-2150S. <http://dx.doi.org/10.1093/jn/134.8.2148S> <PMid:15284423>

Brunetto M.A. 2010. Perda de peso, indicadores do metabolismo de carboidratos e produção de citocinas em cães. Doctoral Dissertation, Faculdade de Ciências Agrárias e Veterinárias, Universidade Estadual Paulista, Jaboticabal, SP. 81p.

Brunetto M.A., Nogueira, S., Sá F.C., Peixoto M., Vasconcellos R.S., Ferraudo A.J. \& Carciofi A.C. 2011. Correspondence between obesity and hyperlipidemia in dogs. Ciência Rural 41(2):266-271. <http://dx.doi.org/10.1590/S010384782011005000004>

Carciofi A.C., Gonçalves K.N.V., Vasconcellos R.S., Bazolli R.S., Brunetto M.A. \& Prada F. 2005. A weight loss protocol and owner's participation in the treatment of canine obesity. Ciência Rural 35(6):1331-1338. <http:// dx.doi.org/10.1590/S0103-84782005000600016>

Eirmann L.A., Fleeman L.M., Laflamme D.P., Michel K.E. \& Satyaraj E. 2009. Comparison of adipokine concentrations and markers of inflammation in obese versus lean dogs. J. Appl. Res. Vet. Med. 7(4):196-205.

Frank L., Mann S., Levine C.B., Cummings B.P. \& Wakshlag, J.J. 2015. Increasing body condition score is positively associated interleukin- 6 and monocyte chemoattractant protein-1 in Labrador retrievers. Vet. Immunol. Immunopathol. 167(3/4):104-109. <http://dx.doi.org/10.1016/j.vetimm.2015.07.010> $<$ PMid:26235599>

Gayet C., Bailache E., Dumon H., Martin L., Siliart B. \& Nguyen P. 2004. Insulin resistance and changes in plasma concentration of TNF $\alpha$, IGF1, and NEFA in dogs during weight gain and obesity. J. Anim. Physiol. Anim. Nutr. 88(3/4):157-165. <http://dx.doi.org/10.1111/j.1439-0396.2003.00473. $\mathrm{x}><$ PMid:15059241>

German A.J. 2006. The growing problem of obesity in dogs and cats. J. Nutr. 136(supl.7):1940S-1946S. <http://dx.doi.org/10.1093/jn/136.7.1940S> <PMid:16772464>
German A.J., Hervera M., Hunter L., Holden S.L., Morris P.J., Biourge V. \& Trayhurn P. 2009. Improvement in insulin resistance and reduction in plasma inflammatory adipokines after weight loss in obese dogs. Domest. Anim. Endocrinol. 37(4):214-226.<http://dx.doi.org/10.1016/j. domaniend.2009.07.001><PMid:19674864>

Hotamisligil G.S., Arner P., Caro J.F., Atkinson R.L. \& Spiegelman B.M. 1995. Increased adipose tissue expression of tumor necrosis factor alpha in human obesity and insulin resistance. J. Clin. Invest. 95(5):2409-2415. <http://dx.doi.org/10.1172/JCI117936> <PMid:7738205>

Ishioka K., Soliman M.M., Sagawa M., Nakadomo F., Shibata H., Honjoh T., Hashimoto A., Kitamura H., Kimura K. \& Saito M. 2002. Experimental and clinical studies on plasma leptin in obese dogs. J. Vet. Med. Sci. 64(4):349353. <http://dx.doi.org/10.1292/jvms.64.349> <PMid:12014581>

Jeusette I.C., Detilleux J., Shibata H., Saito M., Honjoh T., Delobel A., Istasse L. \& Diez M. 2005. Effects of chronic obesity and weight loss on plasma ghrelin and leptin concentrations in dogs. Res. Vet. Sci. 79:169-175. <http://dx.doi. org/10.1016/j.rvsc.2004.11.012> <PMid:15924935>

Laflamme D. 1997. Development and validation of a body condition score system for dogs. Canine Pract. 22(4):10-15.

Leahy J.L. \& Vandekerkhove K.M. 1990. Insulin-like growth factor-I at physiological concentrations is a potent inhibitor of insulin secretion. Endocrinology 126(3):1593-1598. <http://dx.doi.org/10.1210/endo126-3-1593><PMid:2407519>

Mohamed-Ali V., Goodrick S., Rawesh A., Katz D.R., Miles J.M., Yudkin, J.S., Klein S. \& Coppack S.W. 1997. Subcutaneous adipose tissue releases interleukin-6, but not tumor necrosis factor-alpha, in vivo. J. Clin. Endocrinol. Metabol. 82(12):4196-4200. <http://dx.doi.org/10.1210/jcem.82.12.4450> $<$ PMid:9398739>

Shoelson S., Herrero L. \& Naaz A. 2007. Obesity, inflammation, and insulin resistance. Gastroenterology 132(6):2169-2180.<http://dx.doi.org/10.1053/j. gastro.2007.03.059><PMid:17498510>

Tvarijonaviciute A., Tecles F., Martínez-Subiela S. \& Cerón J.J. 2012. Effect of weight loss on inflammatory biomarkers in obese dogs. Vet. J. 193(2):570572. <http://dx.doi.org/10.1016/j.tvjl.2012.02.015><PMid:22464400>

Wakshlag J.J., Struble A.M., Levine C.B., Bushey J.J., Laflamme D.P. \& Long G.M. 2011. The effects of weight loss on adipokines and markers of inflammation in dogs. Brit. J. Nutr. 106(Supl.1):11-14. <http://dx.doi.org/10.1017/ S0007114511000560> <PMid:22005402>

Zoran D.L. 2010. Obesity in dogs and cats: a metabolic and endocrine disorder. Vet. Clin. N. Am., Small Anim. Pract. 40(2):221-239. <http:// dx.doi.org/10.1016/j.cvsm.2009.10.009> <PMid:20219485> 